\title{
Editorial: Religious and Axiological Problems of Identity Politics
}

\author{
Janusz Salamon
}

Charles University

Due to the popularity of the "secularisation thesis" and of mainstream liberalism's neutrality in matters of religion, ethics and moral norms, the political sciences in the second half of the 20th century were marked by the relative absence of a scholarly debate about the political relevance of religious and axiological beliefs. The turn of the century witnessed a robust return of religion and axiology to political theory in the form of "identity politics," which appears to still be on the rise after two decades rather than in decline.

The current issue includes eight essays which explore various religious and axiological aspects of identity politics. The authors strive both to map the challenges resulting from religious and value pluralism and to outline the conditions of constructively accommodating religious and axiological traditions within a broadly liberal political order. Methodologically speaking, the essays belong to the realm of political philosophy, and while some of them entail certain policy recommendations, their main contribution is meant to be theoretical in nature.

The stage is set by Joseph Rivera's expansion of John Rawls' classic proposal of accommodating religious and value pluralism within a liberal "overlapping consensus." Rivera tries to mediate between the narrative of identity politics that appear to challenge the liberal order and the narrative of liberal dialogue within a hermeneutical framework of civic friendship aimed at deflating partisan rivalry. He argues that liberalism need not be understood as a theory of how one may best "leave each alone" as isolated social atoms, but it can instead foster a robust dialogue not only among individuals but among larger social groups grounded in particular traditions as well. In this way, liberalism helps negotiate pluralism without giving up morally "thick lifeworlds."

Göran Collste also adopts John Rawls' theory of liberal tolerance and pluralistic consensus as the horizon of his exploration of "epistemic injustice" as a current socio-political phenomenon constituting an extension of Western cultural domination and the cultural parochialism of a colonial past. Collste identifies the danger of distorting the liberal values

\footnotetext{
* Janusz Salamon, Institute of Political Studies, Faculty of Social Sciences, Charles University, U Kř́rže 8, 15800 Prague, Czech Republic; janusz.salamon@fsv.cuni.cz
} 
of respect, reciprocity and tolerance through the external imposition of a particular (Western) value framework that forces a (non-Western) culture into cultural subjection and threatens the dominated people's epistemic framework, collective identity and existential security. Collste argues that Rawls' theory of political liberalism provides conceptual tools for global intercultural relations that are free of one-sided claims to epistemic superiority.

Marius Timmann Mjaaland engages critically with Hans Joas' alternative to Max Weber's theory of secularisation as disenchantment. According to Joas, there was never such a thing as a merely secular society, only the objects that are sacralised keep changing. As a result of this, many societies have constructed the nation as sacred in the $19^{\text {th }}$ and $20^{\text {th }}$ centuries while-according to Joas - we are currently witnessing a tendency towards the sacralisation of the person in the ideology of the universal values of human rights. While Mjaaland agrees that human rights may replace religion in its role as a common source of political ideals and as the foundation for national laws, he argues that human rights represent a "secular formatting of the sacred" and do not capture some of the aspects of the religious sacrum.

Peter Jonkers plunges into the set of challenges related to value pluralism, taking the backlash against the model of a multicultural society that has been cultivated for decades with mixed results in his native Netherlands as well as in other Western European countries as a point of departure. Jonkers' diagnosis of the problem is that value pluralism leads to conflicts because it challenges people's fragile socio-cultural identity. He argues that the "modernisation theory," according to which substantial socio-cultural values were meant to be replaced over time by a universalist, rational and procedural ethics, has not come true. Searching for the light at the end of the tunnel, Jonkers considers Charles Taylor's overoptimistic plea for a broadening of our socio-cultural horizon and a transformation of our common standards of value judgements, based on his idea of a fusion of cultural horizons. In place of Taylor's framing, Jonkers formulates the idea of "cultural hospitality" based on an application of Paul Ricoeur's idea of linguistic hospitality to the cultural sphere, which recognizes the unbridgeable gap that separates different cultures and their values.

Riceour's idea of interreligious dialogue as a specific form of linguistic hospitality provides a background for Marianne Moyaert's search for a nonviolent and transformative space of encounters for learning in a religiously pluralistic classroom. She notices that a normative distinction between good (mature) and bad (immature) religiosity that is tacitly presupposed in Western societies contributes to testimonial and hermeneutical injustice 
in pluralistic classrooms because it results in the marginalisation of some of the students, especially those whose religious practices do not fit the understanding of what religion ought to be. Moyaert's concern is that interreligious educators who profile themselves as cultural brokers projecting a vision of interfaith solidarity and increased social cohesion may in practice contribute, by uncritically promoting the normative distinction between good and bad religion, to testimonial and hermeneutical injustice, reproducing inequalities and exclusion.

Ivana Noble explores changes in contemporary religiosity in the Czech Republic with a special focus on the capability of religion to give rise to solidaristic action. She asks whether there are any possible connections between the current absence of welcome of Syrian refugees and the fact that the dominant type of religiosity in the Czech Republic despises religious dogmas and institutions. She asks how people believing in "something," all while not wishing to define that "something" or share its vision with others, can make an informed and healthy judgment and make them capable of solidarity with others. Applying a multidimensional theory of religion, she argues that it is vital not to give up on the criteria for judging between what is superstition and what is faith, what is selfish and what is generous, what is and what is not our responsibility in times of humanitarian crisis, etc. She argues that the lack of a solidaristic response to the recent refugee crisis in the Czech Republic can be explained in part by the fact that when appeals to Christian values become content-less and are used to defend xenophobia and nationalism, it is easy to keep this absence of content in operation when negative sentiments against religious doctrines and institutions of others are exploited.

Stanislaw Obirek explores various aspects of the phenomenon of "postsecularism" as capturing the current conflicts between secular and religious worldviews. Discussing various recent theories of postsecularism, he puts forward his own interpretation of postsecularism as a form of pluralism. As such, postsecularism appears to challenge some of the assumptions of both believers and non-believers in a constructive manner, creating a space for worldview dialogue between believers and non-believers with important political implications for pluralistic societies.

Fedor Stanzhevsky and Dmitri Goncharko address the issue of the plurality of Russian identities. They challenge the traditional idea of the two opposed Russian identities (those of the elite and of the common people) by suggesting a third Russian identity shaped by the followers of the Old Belief after the split of the Russian Church. The Old Believers, due to their worldview and way of 
thinking and living, gave rise to a new anthropological figure which contrasts with the stereotyped image of the Russian grounded in the history of serfdom and a rural community. This new type of Russian identity is associated with democratic governance, a rigorous way of life, a higher rationality and dynamic as well as successful economic activity. Stanzhevsky and Goncharko argue that the history of the Russian Schism reveals a latent tension within the post-Communist search for a new Russian identity. Unlike the religious wars in Europe, this conflict received no resolution; instead, it has been repressed and has therefore continued to latently affect the Russian present. Present-day Russia should draw inspiration in the religious and political heritage of the Old Believers if the conflict is to be resolved. 